\title{
Серебряное перо Русского Путешественника: к прочтению одной сложной литературной истории *
}

\section{The Silver Quill of the Russian Traveler: Towards a Reading of One Complicated Literary History}

\author{
Степан Денисович Попов \\ Национальный исследовательский университет - Высшая школа экономики (Санкт \\ Петербург) \\ Stepan Denisovich Popov \\ National Research University - Higher School of Economics (St. Petersburg) \\ stepanpopov15@gmail.com
}

\begin{abstract}
:
This article focuses on Karamzin's seemingly off-hand remark about the fact that all the Letters of a Russian Traveler were written not with the traditional goose-feather quill-, but rather silver-nibbed pen. A brief study of late-18th century metal pens and their cultural connotations shows that the silver pen in this period was not only a new, fashionable, and convenient writing implement, but also a symbol for the arrival of the modern era. And, as a close reading of Letter of a Russian Traveler demonstrates, that is also the case for the protagonist's repeated references to his silver pen. The author argues that Karamzin's invocation of this meaning-laden writing implement, especially in connection with his appropriation of the philosophy of Immanuel Kant, made it possible for the Russian novelist to offer his readers a series of remarkable ideological statements about enlightenment in general, and Russia's place in the modern world in particular.
\end{abstract}

Ключевые слова:

Карамзин, Письма Русского Путешественника, серебряное перо, Кант, Просвещение, публичная сфера, модерность, литературная прагматика, культурная политика

Keywords:

Karamzin, Letters of a Russian Traveler, silver pen, Kant, Enlightenment, public sphere, modernity, literary pragmatics, cultural politics

Но вещи рвут с себя личину,

Теряют власть, роняют честь, Когда у них есть петь причина, Когда для ливня повод есть.

Если обобщить большинство известных отрицательных отзывов современников о Карамзине и его ранних публикациях, ${ }^{1}$ то на выходе можно получить следующую

\footnotetext{
* Пользуясь случаем, хочу поблагодарить Андрея Костина за оказанную помощь и поддержку в ходе
} работы над этой статьей, а также - за поданный им повод поразмышлять об интереснейшем историко- 
любопытную конструкцию: Письма русского путешественника [далее - либо Письма, либо ПРП], самое значительное из ранних произведений Карамзина, оказывается наполненным бессмысленными, бесполезными для читателя деталями; а их автор излишне пристрастным к описанию европейского быта, вещей в целом.

Самый очевидный здесь для профессионального интерпретатора шаг: увидеть за этими оценками желание консервативной части критиков отстоять некий нормативный литературный образец (то, как и о чем следует писать). Однако подобная редукция, с одной стороны, литературно-прагматической составляющей карамзинского повествования, а с другой - отличительной “материальности” его текста, в конечном итоге лишает изображенные писателем вещи какого-либо субстанционального статуса, объективирует их; ${ }^{2}$ а вменение автору невротической фиксации на материальных предметах сводит до уровня банальной инвективы (впрочем, каковой Карамзин вполне мог ожидать и даже сознательно добиваться, отметит все тот же интерпретатор). Очевидная теоретико-методологическая предпосылка производит и очевидную же интерпретацию, а иногда и побуждает совершать грубые ошибки, грубые суждения об исследуемом произведении (иногда даже фатальные, как покажет дальнейший анализ).

Вещи, как показывает Кристина Ионеску, в эпоху Просвещения семантизируют социальное и культурное пространство, обращают быт в дискурс. ${ }^{3}$ Описания же вещей в литературных текстах этого периода, соответственно, не только репрезентируют какие-либо значения, но и позволяют авторам популяризировать дискурсивно связанные с ними культурные практики и тем самым воздействовать на своего читателя. То же - в полной мере характерно для Карамзина и его Писем. ${ }^{4}$

В этой перспективе упоминание того, что Русский Путешественник [далее - либо Путешественник, либо РП] пишет свои Письма серебряным пером, а не обычным гусиным, и тот факт, что это обстоятельство дополнительно оговаривается им в комментарии к произведению, - представляются специально мотивированными, а рассказ о них содержательно наполненным. Прочтение и последующий анализ этой сложной литературной истории позволит не только идентифицировать, какие культурные практики Карамзин в данном случае стремился культивировать в русском читающем обществе (и с чем, в действительности, боролись критически настроенные современники), но и позволит сделать несколько генерализованных, более общих суждений о ПРП: в частности, даст возможность уточнить значение бытовой детали в Письмах и интерпретировать ее специфический прагматический характер не только в

${ }^{1}$ Примеры чего см. в Н. Кочеткова, “Читательские отклики на публикации Карамзина XVIII века,” в $A$ Century Mad and Wise. Russia in the Age of Enlightenment: Papers from the IX International Conference of the Study Group on Eighteenth-Century Russia, Leuven, eds. E. Waegemans, H. van Koningsbrugge, M. Levitt and M. Ljustrov (Groningen: Netherlands Russia Centre, 2015), 11-20. (N. Kochetkova, “Chitatel'skie otkliki na publikatsii Karamzina XVIII veka”) в A Century Mad and Wise. Russia in the Age of Enlightenment: Papers from the IX International Conference of the Study Group on Eighteenth-Century Russia, Leuven, eds. E. Waegemans, H. van Koningsbrugge, M. Levitt and M. Ljustrov (Groningen: Netherlands Russia Centre, 2015), 11-20.

${ }^{2}$ Bruno Latour, "Why Has Critique Run out of Steam? From Matters of Fact to Matters of Concern," Critical Inquiry, 30 (2004): 225-248.

3 Christina Inosecu, "Through the Prism of Thing Theory: New Approaches to the Eighteenth-Century World of Objects," в Eighteenth-Century Thing Theory in a Global Context: From Consumerism to Celebrity Culture (Farnham: Ashgate, 2013), 17-31.

${ }^{4}$ О чем см., например, A. G. Cross, N. M. Karamzin: A Study of His Literary Career (1783 - 1803) (Carbondale: Southern Illinois University Press, 1971). 
связи с рецепцией Карамзиным просвещенческого дискурса, но и в контексте актуальной для писателя модели литературного письма и возникающих с ней внелитературных интенций.

Но прежде всего следует взглянуть на серебряное перо как на вещь, реконструировать ее “биографию,” а также попытаться установить причины, по которым Карамзин мог интересоваться последней.

\section{Серебряное перо: от орудия письма к культурному значению}

Как пишет Соломон Рейсер, металлическое перо в первоначальном виде “имело форму трубки или цилиндрика со сходящимися краями, образующими посередине щель ... боковые стороны которого были обрезаны так же, как у гусиного пера.” 5 Несмотря на ряд технических недостатков, этот тип пера по своим общим характеристикам значительно превосходил гусиное: так, например, металлическое перо значительно облегчало процесс письма, поскольку реже требовало починки; позволяло писать с большей скоростью, так как не разбрызгивало чернила по бумаге и не издавало характерного неприятного скрипа. Также, как добавляет исследователь, появление металлических перьев способствовало индивидуализации почерка пишущего, чему гусиные перья всячески препятствовали. Это было связано с тем, что для того, чтобы писать гусиным пером, требовалось обладать весьма специфическим навыком, притом весьма трудным в освоении, требующим перманентной тренировки и задающим единый, универсальный стиль письма (о чем можно судить, например, по следующим методикам обучения: “для приобретения необходимых навыков письма... рекомендовались особые приемы, вплоть до перевязывания отдельных пальцев и подтягивания их к кисти руки... [...] в перо втыкались булавки, для того чтобы рука не могла опуститься ниже определенной линии." ${ }^{\circ}$ Металлические перья отменили эти сложности. Первые такие письменные инструменты появились в России лишь во второй трети XIX века. До этого - такие перья стоили весьма дорого, были крайне труднодоступны и, как отмечает Лев Черепнин, отличались “несовершенством выделки."

Относительно же того, когда первые металлические перья появились в Европе, существует много споров: большая часть из них описана в книге Генри Бора, The Story of the Invention of Steel Pens With a Description of the Manufacturing Process by Which They Are Produced. Как отмечает Бор, металлические перья начинают продаваться в Европе ближе к середине-концу XVIII века и при этом являются статусным предметом,

\footnotetext{
${ }^{5}$ Соломан Абармович Рейсер, “Орудия письма,” Палеография и текстология нового времени (Москва: Просвещение, 1970), 20-34, здесь 25. (Solomon Abramovich Reiser, “Orudiia pis'ma," Paleografiia i tekstologiia novogo vremeni (Moscow: Prosveshcheniie, 1970), 20-34, zdes' 25). Большинство палеографических исследований - при описании первых металлических перьев - нередко игнорируют тип металла, из которых последние были изготовлены. В связи с этим необходимо оговорить, что в большинстве случаев эти перья были именно серебряные, реже - золотые; стальные же перья - появятся значительно позже, уже совсем в другую технологическую эпоху. О связанных с ними культурных коннотациях см., например, Thomas DeGregori, “Technology, Industrialization, and Creativity,” в Bountiful Harvest: Technology, Food Safety, and the Environment (Washington, D.C.: Cato Institute, 2002), 31-61.

${ }^{6}$ Рейсер, “Орудия письма," 21. (Reiser, “Orudiia pis'ma,” 21).

7 Лев Владимирович Черепнин, Русская палеография (Москва: Политиздат, 1956), 540. (Lev Vladimirovich Cherepnin, Russkaia paleografiia (Moscow: Politizdat, 1956), 540).
} 
одновременно и весьма дорогим аксессуаром, и весьма дорогим орудием письма. 8 Тем не менее, серебряные и золотые перья использовались и ранее. Важно отметить, что узус их бытования и практического применения - в первую очередь, в силу слабой распространенности - был весьма специфическим. Так, например, английский поэт Эдмунд Уоллер еще в XVII веке пишет стихотворение “To a Lady, from Whom He Received a Silver Pen,” в котором благодарит некую знатную даму за столь ценный подарок и к этому добавляет: “That your great self did ne'er indite / Nor that to me more noble write." 9

Несомненно, между автором стихотворения и дамой, подарившей ему серебряное перо, выстраиваются иерархически неравные отношения. Также несомненно, что выбор такого подарка был продиктован именно профессиональными занятиями Уоллера. Фактически, серебряное перо обретает здесь иное, помимо своего материального и статусного, значение: это указание на профессиональную идентичность принимающего подарок. Схожие коннотации относительно серебряного пера обнаруживает Мариса Басс в своей работе о Юсте Липсии, нидерландском историке и филологе XVI-XVII века. Исследовательница подчеркивает, что тот факт, что Липсий использует в качестве орудия письма именно серебряное перо, а не какоелибо другое, определялось им как метафора, задающая границы не только его профессиональной, но также социальной и культурной идентичности: соответственно, как писателя и ренессансного гуманиста. ${ }^{10}$ В свою очередь, эта метафора может быть прочитана не только как идентичностный маркер, но и как качественное определение: то, что пишется серебряным пером, обретает особенный, “высокий” статус; и следовательно, его владелец определяется не просто как лицо, связанное с интеллектуальным трудом, а как, опять-таки, “высокий” автор, ведущий отборную речь об отборных же предметах и темах.

Неизвестно, как Карамзин воспринимал и оценивал эти культурные значения. Ясно лишь, что серебряное перо для писателя - это, как и для многих его современниковевропейцев, подходящий для путешествия инструмент. Наконец появившиеся в болееменее широкой продаже, металлические перья были чрезвычайно удобны для путешественников конца XVIII века: здесь принимались в расчет и их портативность, и их долговечность. ${ }^{12}$ Дело же интерпретации стоящей за этими перьями культурной традиции остается за РП, то есть за фикциональным представителем Карамзина в тексте Писем.

\footnotetext{
${ }^{8}$ Henry Bore, The Story of the Invention of Steel Pens With a Description of the Manufacturing Process by Which They Are Produced (New York: Ivison, Blakeman \& Company, 1890).

${ }^{9}$ Edmund Waller, Poems: EC., Written Upon Several Occasions, and to Several Persons, 5 th edition (London: H. Herringman, 1686), 107.

${ }^{10}$ Marisa Bass, "Justus Lipsius and His Silver Pen," Journal of the Warburg and Courtauld Institutes, 70 (2007): 157-194.

${ }^{11}$ Тем не менее, как отмечает Черепнин, Русская палеография, 4о (Cherepnin, Russkaia paleografiia, 40), Карамзина чрезвычайно занимала палеография, причем исключительно в своем “практическом” аспекте: “Карамзин в примечаниях к своей Истории привел большое количество палеографических наблюдений над источниками [...] По выражению одного позднейшего исследователя, И. И. Срезневского, из них можно было бы 'выделить большую книгу записок о древних памятниках русской письменности.” Возможно, что этот позднейший интерес Карамзина к палеографии возник именно благодаря когда-то привлекшим его внимание серебряным перьям.

${ }^{12}$ Esther Moir, Discovery of Britain: The English Tourists, 1540-1840 (London: Routledge \& Kegan Paul, 1964).
} 
Карамзин, первичный автор Писем, воспринимая различные европейские влияния и моды, доверяет рассказ о них, их прочтение именно РП, вторичному автору; ${ }^{13}$ фактически, создает дополнительный медиум между собой и читателем. Критический потенциал этого медиума Григорий Гуковский оценивает как исключительно высокий: “Весь объективный материал... Карамзин показывает не сам по себе, а как свое личное переживание." 14 Это означает, что серебряное перо, возникая в ПРП, - и при этом сохраняя высокую символическую значимость, - теряет четкость готовых интерпретаций и оказывается чем-то принципиально новым, творимым на месте посредством самого текста. И более того, реализующим свой потенциал исключительно в процессе рассказывания (и чтения же) истории Путешественника; по сути, в самом тексте Писем.

То же, какой смысл вкладывал в фигуру серебряного пера Карамзин, или как его собственные размышления могли повлиять на характер появления пера в произведении, возможно определить лишь реконструктивно (что отчасти и будет сделано в дальнейшем).

\section{Серебряное перо: презентация эпизода}

Впервые о том, что Путешественник пользуется серебряным пером, читатель узнает в седьмом письме:

Но перервем разговор, который занял уже с лишком две страницы и начинает утомлять серебряное перо мое [курсив мой - СП]. Словоохотный поручик до десяти часов наговорил с три короба, которых я, жалея Габриелевых лошадей, не возьму с собою [...] Чего не напишешь в минуты бессонницы. ${ }^{15}$

РП описывает свою случайную встречу с неким немецким поручиком в корчме. Впечатления от беседы с ним, впечатления от дальнейшего автобиографического рассказа неизвестного поручика РП оценивает как нечто, что не заслуживает какоголибо серьезного внимания, - и, соответственно, мотивирует рассказ читателю о последних лишь целью побороть бессонницу. В следующем письме приводится пересказ разговора Путешественника с Кантом, несомненно, более для него значимый, чем предыдущий с поручиком; и к тому же, имеющий не случайный, а

\footnotetext{
${ }^{13}$ На важности соблюдения этой иерархии указывают многие исследователи. Так, например, Юрий Лотман, Сотворение Карамзина (Москва: Книга, 1987) (Iurii Mikhailovich Lotman, Sotvoreniie Karamzina (Moscow: Kniga, 1987) считал, что РП - это художественный образ, который Карамзин сознательно конструировал и которому, по его мысли, должен был подражать каждый читатель Писем. В дальнейшем этот лотмановский тезис будет критически переосмыслен. Пока что же, с критикой подобного взгляда на ПРП можно ознакомиться, например, в статье А. Чудинова, “Лотман, Карамзин, Ромм: реконструкция одной реконструкции," Неприкосновенный запас, № 3 (59) (2008): 224-231. (A. Chudinov, "Lotman, Karamzin, Romm: rekonstruktsiia odnoi rekonstruktsii," Neprikosnovennyi zapas, 3:59 (2008): 224-231).

14 Григорий Александрович Гуковский, Русская литература XVIII века (Москва: Аспект Пресс, 1999), 351372, здесь, 365. (Grigorii Aleksandrovich Gukovskii, Russkaia literature XVIII veka (Moscow: Aspekt Press, 1999), 351-372, zdes' 365).

${ }^{15}$ Н. Карамзин, Письма русского путешественника. Изд. подгот. Ю. М. Лотман, Н. А. Марченко, Б. А. Успенский (Ленинград: Наука, 1984), 19. (N. Karamzin, Pis'ma russkogo puteshestvennika. Izd. podgot. Iu. M. Lotman, N. A. Marchenko, B.A. Uspenskii (Leningrad: Nauka, 1984), 19).
} 
интенциональный характер. ${ }^{16}$ Эта беседа производит на Путешественника следующий эффект:

Вот вам, друзья мои, краткое описание весьма любопытной для меня беседы... - Кант говорит скоро, весьма тихо и невразумительно; и потому надлежало мне слушать его с напряжением всех нерв слуха. Домик у него маленький, и внутри приборов немного. Все просто, кроме... его метафизики. ${ }^{17}$

Располагая обе беседы друг за другом, РП тем самым задает здесь рамку цельного микро-эпизода, где восьмое письмо является логическим продолжением седьмого. Не вызывает сомнения, что РП видит различие между поручиком и Кантом и что он вполне иерархично их сравнивает: если обсуждение “непростой метафизики” с философом представляется Путешественнику важным, то “наговоренное с три короба словоохотливым поручиком” ему, наоборот, представляется неважным. Контрастность этих описаний - лишь повод для их сопоставления. Еще одним таким поводом, пускай и не столь эксплицитным, становится ввод фигуры серебряного пера. Так, в первом отдельном книжном издании ПРП ${ }^{18}$ в комментарии как раз к седьмому письму Путешественник еще раз оговаривается, что этот текст, - как, впрочем, и все остальные (а значит, и восьмое письмо: на это обстоятельство, по-видимому, здесь и делается прямое, непосредственное указание), - был написан им именно серебряным, а не привычным гусиным, пером: “Все свои замечания писал я в дороге серебряным пером."

Ввод этой мелкой, но в данном случае существенной детали, - к тому же, выделенной в отдельное паратекстовое пространство, то есть специально эмфатизированной автором, - дополнительно проблематизирует указанный микроэпизод и выводит его на более концептуально важный уровень: простое оценочное сравнение поручика и философа превращается в размышление о достойных и недостойных описания Путешественником сюжетов. Фигура пера в этой перспективе обретает перформативную функцию, работает как некая дескриптивная категория. Для того, чтобы сделать шаг к пониманию этого сложного значения, требуется согласиться с правилами чтения Писем, принять специфику их взаимодействия с читателем. В этом отношении немаловажно, что фигуру серебряного пера возможно прочитать по тропеической модели, а именно - по модели метонимии. О том, насколько значимой эта риторическая фигура является для РП и его повествовательного стиля, можно судить по следующему отрывку из текста Писем:

\footnotetext{
${ }^{16}$ Как отмечает Алла Койтен, визит РП к Канту органично вписывался в немецкую традицию образовательных поездок (Bildungsreise), весьма важную для эпохи Просвещения. А. Койтен, “Немецкий писатель Карамзин," Новое литературное обозрение, 6о:2 (2003): 96-105. (Alla Koiten, "Nemetskii pisatel' Karamzin," Novoe literaturnoe obozrenie, 6o:2 (2003): 96-105). Суть этой традиции состояла в том, что немецкие студенты (и образованные молодые люди из других стран) по окончании своего обучения путешествовали по Европе и встречались с крупнейшими интеллектуалами своего времени: таким образом, встреча РП и Канта есть не исключение, а закономерность; не спонтанное желание Путешественника, а продуманное им заранее мероприятие.

${ }^{17}$ Карамзин, Письма русского путешественника, 21. (Karamzin, Pis'ma russkogo puteshestvennika], 21).

${ }^{18}$ Стоит отметить, что в первой журнальной публикации Писем отдельного авторского комментария о серебряном пере - нет. По-видимому, желание каким-либо образом отметить этот эпизод возникло у Карамзина не сразу, а ретроспективно.

19 Карамзин, Письма русского путешественника, 19. (Karamzin, Pis'ma russkogo puteshestvennika, 19).
} 
Я отираю слезы свои - и радуюсь, что я Руской [...] Жаль только, что французы нарядили государя, Менщикова и Лефорта в польское платье, а Преображенских солдат и офицеров - в крестьянские зеленые кафтаны с желтыми кушаками. Зрители вокруг меня говорили, что русские и ныне точно так одеваются, а я, занимаясь драмою, не почел за нужное выводить их из заблуждения. ${ }^{20}$

РП, описывая опыт своего просмотра мелодрамы Петр Великий в Итальянском театре в Париже, ${ }^{21}$ дает весьма любопытный образец метонимической организации повествования: персонажи, окружающее их сценическое пространство, определяемые автором через категории национальной идентичности, то есть как “русские” - служат поводом для возникновения у Путешественника, с одной стороны, экстатических чувств (“я отирая слезы свои”), а с другой стороны, национальных, патриотических (“и радуюсь, что я Руской”). ${ }^{22}$ И даже то, что Петр I или Меншиков одеты в пьесе в “чужое” платье, ${ }^{23}$ не вызывает у Путешественника каких-либо серьезных нареканий. Сам факт метонимической номинации какого-либо предмета или объекта как “русского” дает ему возможность рефлексировать о границах своей субъектности. И тем любопытнее на этом фоне то, что фигура повествователя, все так же метонимически определяемая как русская, не столько отделяется от окружающих ее иностранцев, носителей иной, “чуждой” идентичности; сколько объявляет свой гипотетический с ними спор или конфликт бессмысленным, бессодержательным. Метонимия, используемая как основной принцип организации повествования и отношений между персонажами, позволяет тексту ПРП остранить существующую традицию критики уровня европейских знаний о России и образах ее повседневности. ${ }^{24}$

Критическое переосмысление мотива осуждения иностранцев, не знающих “подлинной” русской культуры, не умеющих отличать “польское” платье от "русского," - есть то новое знание, которое Путешественник производит с помощью своего

${ }^{20}$ Карамзин, Письма русского путешественника, 241. (Karamzin, Pis'ma russkogo puteshestvennika, 241).

${ }^{21}$ Более подробные сведения о спектаклях, посещенных Карамзиным в Париже, можно найти в статье Петра Заборова, “'Русский Путешественник' в Парижской Большой опере,” Карамзин-писатель: коллективная монография, ред. Н. Д. Кочетковой, А. Ю. Веселовой, Р. Бодэна (Санкт-Петербург: Пушкинский Дом, 2018), 81-91. (Petr Zaborov, "Russkii Puteshestvennik' v Parizhskoi Bol'shoi opere," Karamzin-pisatel': kollektivnaia monografiia, red. N. D. Kochetkovoi, A. Iu. Veselovoi, R. Bodena (St. Petersburg: Pushkinskii Dom, 2018)], 81-91).

${ }^{22}$ То, в какой степени поведение Карамзина и его героя определяется национальными, патриотическими или, напротив, космополитическими идеями, - тема для отдельного разговора. С внимательным анализом этой проблемы можно ознакомиться, например, в книге Дерека Оффорда: Derek Offord, Journeys to a Graveyard: Perceptions of Europe in Classical Russian Travel Writing [Archives internationales d'histoire des idées, 192] (Dordrecht: Springer, 2005).

${ }^{23} \mathrm{O}$ том, как объекты моды в екатерининскую эпоху оказывались репрезентантами дискурсивных систем (в том числе - и систем национальной идентичности) см. подробнее: Victoria Ivleva, Frills and Perils of Fashion: Politics and Culture of the Eighteenth-Century Russian Court through the Eyes of La Mode," EighteenthCentury Thing Theory in a Global Context: From Consumerism to Celebrity Culture, eds. Ileana Baird and Christina Ionescu (Farnham: Ashgate, 2013), 113-133; К. Бордэриу, Платье императрицы и европейский костюм в Российской Империи (Библиотека журнала “Теория моды”) (Москва: Новое литературное обозрение, 2016). (K. Borderiu, Plat'e imperatritsy i evropeiskii kostium v Rossiiskoi Imperii (Biblioteka zhurnala "Teoriia mody") (Moscow: Novoe literaturnoe obozrenie, 2016).

${ }^{24}$ Евгений Рудольфович Пономарев, “Русский имперский травелог," Новое литературное обозрение, № 2 (144) (2007): 33-44. (Evgenii Rudol'fovich Ponomarev, "Russkii imperskii travelog," Novoe literaturnoe obozrenie, 2:144 (2017): 33-44). 
метонимического рассуждения. “Русскость,” по мнению Путешественника, оказывается категорией не свойственной какому-либо объекту изначально, а возникающей контекстуально (то есть, являющейся фикциональной, “воображаемой,” если следовать здесь языку классических исследований национализма), и по этой причине - спор о последней теряет в глазах Путешественника прежнюю значимость. То же и в случае с серебряным пером: оставляя ему статус материального объекта, приметы современного европейского быта, РП, следуя строгой метонимической логике, задает последней иной вектор, иную тематическую и функциональную перспективу.

И если в первом случае метонимически замещенное значение эксплицируется с помощью отдельного авторского маркера (“не почел за нужное выводить их из заблуждения” [курсив мой - СП]), то в случае с пером такое замещенное значение может быть прочитано лишь после более внимательного анализа пересказанных Путешественником бесед, их коммуникативного потенциала и речевого контекста.

\title{
Карамзин и Кант: апроприация теории, серебряное перо как способ Просвещения и как орудие модерного общества
}

Пересказывая свою беседу с Кантом, Путешественник пишет следующее:

\begin{abstract}
Деятельность есть наше определение. Человек не может быть никогда совершенно доволен обладаемым, и стремится всегда к приобретениям. Смерть застает нас на пути к чему нибудь, что мы еще иметь хотим. Дай человеку все, чего желает; но он в ту же минуту по чувствует, что это $\underline{\text { все }}$ не есть все" [...] "Помышляя о тех услаждениях, которыя имел я в жизни, не чувствую теперь удовольствия; но представляя себе те случаи, где действовал сообразно с законом нравственным, начертанным у меня в сердце, радуюсь. ${ }^{25}$
\end{abstract}

Исследователь Ирвинг Энеллис, комментируя указанный отрывок, пишет о нем как о “популярном изложении Критики критического разума," ${ }^{26}$ где философ выступает как создатель теоретической модели, а Путешественник как ее пассивный истолкователь. Подобное прочтение беседы РП с Кантом - небесспорно. Помимо очевидной интертекстуальной составляющей - и отмеченной здесь интерпретатором кантовская речь в данном случае любопытна как репрезентация философского дискурса, как речь философа как такового (и потому сравниваемая Путешественником с речью анонимного поручика: то есть, поручика как такового). Эта повествовательная установка определяет и логику, и смысл конструируемого здесь микро-эпизода в целом.

В своей знаменитой работе 1784-го года Кант, описывая Просвещение как процессуальное явление, рассуждает не столько о том, каким по итогу должен

\footnotetext{
${ }^{25}$ Карамзин, Письма русского путешественника, 20-21. (Karamzin, Pis'ma russkogo puteshestvennika, 2021).

26 Ирвинг Энеллис, “Беседа Николая Михайловича Карамзина с Иммануилом Кантом. Популярное изложение Иммануилом Кантом Критики критического разума,” Кантовский сборник, № 1: 27 (20о8): 109-120. (Irving Enellis, "Beseda Nikolaia Mikhailovicha Karamzina s Immanuilom Kantom. Populiarnoe izlozhenie Immanuilom Kantom Kritiki kriticheskogo razuma,” Kantovskii sbornik 1:27 (2008): 109-120).
} 
получиться просвещенный субъект, сколько о механизмах его воспитания. ${ }^{27}$ Основным таким механизмом, по мнению философа, должна выступать практика активного вовлечения индивида в различные дискуссии и споры, активное побуждение (или в редких случаях - даже принуждение $)^{28}$ его к речи. Тема и состав участников такого дебата не имеют значения. Важно лишь, чтобы разговор был “публичным": то есть, одновременно свободным и от каких-либо цензурных ограничений, и от использования каких-либо “готовых” риторических формул и понятий. ${ }^{29}$ Таким образом, Кант смещает оптику своего анализа с содержания речи просвещенного субъекта на те нормативные приемы, по которым она обязана строиться. Не цитируя и не ссылаясь, а апроприируя кантовские идеи, Путешественник, соответственно, производит сравнительный анализ речевых тактик философа и поручика на предмет их соответствия выделенных Кантом - Приемов Просвещения.

В перспективе установления этой связи обратимся к разговору РП с поручиком, антиподом философа:

Я. Из Петербурга, господин поручик.

Поручик. Радуюсь, радуюсь, государь мой. Что слышно о шведах, о турках?

Я. Старая песня, господин поручик; и те и другие бегают от русских.

Поручик. Черт меня возьми! Русские стоят крепко... У меня везде не без друзей. Например, племянник моя служит старшим адъютантом у князя Потемкина. Он ко мне обо всем пишет. Постойте - я покажу вам письмо его. Черт меня возьми! Я забыл его дома. Он описывает мне взятие Очакова. Пятнадцать тысяч легло на месте, государь мой, пятнадцать тысяч!

Я. Неправда, господин поручик.

Поручик. Неправда? (С насмешкою.) Вы, конечно, сами там были?

Я. Хоть и не был, однако ж знаю, что турков убито около 8ооо, а русских 1500.

Поручик. О! Я не люблю спорить, государь мой; а что знаю, то знаю. (Принимаясь за кружку, которую между тем принесла ему хозяйка.) Разумеете ли, государь мой $?^{30}$

\footnotetext{
${ }^{27}$ На это, в свою очередь, обратил внимание Мишель Фуко: “it [Просвещение - прим. СП] has to be conceived as an attitude, an ethos, a philosophical life in which the critique of what we are." Michel Foucault, "What is Enlightenment?," The Foucault Reader, ed. Paul Rabinow (New York: Pantheon Books, 1984), 32-51, здесь 50. Просвещение определяется здесь как этос, как философская установка, а не как некое субстанциональное знание - или набор “правильных” слов, из которых должна складываться “правильная" речь.

${ }^{28}$ Об этом аспекте кантовской концепции в связи с постколониальной теорией см., например: Александр Эткинд, "История приходит к Канту," Внутренняя колонизация. Имперский опыт России, пер. В. М. Макаров (Москва: Новое литературное обозрение, 2013), 273-303. (Aleksandr Etkind, "Istoriia prikhodit k Kantu," Vnutrenniaia kolonizatsiia. Imperskii opyt Rossii, per. V. M. Makarov (Moscow: Novoe literaturnoe obozrenie, 2013), 273-303). О рецепции Канта в Российской Империи также см. Thomas Nemeth, Kant in Imperial Russia (Cham: Springer, 2017).

${ }^{29}$ Иммануил Кант, “Ответ на вопрос: Что такое Просвещение?,” в Сочинения в шести томах, т. 6, ред. В. Ф. Асмуса. А. В. Гулыги и Т. И. Ойзермана (Москва: Мысль, 1966), 25-37, здесь 27-29. (Immanuel Kant, "Otvet na vopros: Chto takoe Prosveshchenie?," v Sochineniia v shesti tomakh, t. 6, red. V. F Asmusa, A.V. Gulygi i T. I. Oizermana (Moscow: Mysl', 1966), 25-37, zdes' 27-29).

30 Карамзин, Письма русского путешественника, 17-18. (Karamzin, Pis'ma russkogo puteshestvennika, 1718).
} 
Разговор Путешественника и поручика происходит в корчме: то есть, в локусе публичной сферы. ${ }^{31}$ Согласно Канту, находясь в публичной сфере, пользуясь возможностями, которые она предоставляет, субъект имеет шанс не только свободно размышлять, но еще и совершенствовать свои коммуникативные навыки, а через это и “просвещаться," в конечном итоге обретать “совершеннолетнее состояние." 32 Примечательно, что поручик, находясь в границах публичной сферы, этим шансом не пользуется. Здесь важны следующие обстоятельства: во-первых, поручик при разговоре о ведущихся Россией войнах спорит с Путешественником относительно количества погибших в том или ином сражении; ${ }^{33}$ во-вторых, интерес поручика к этим событиям обусловлен его социальным положением, его причастностью к определенной социальной корпорации (военных, армии: институции, где, помимо прочего, роль логоса сведена к минимуму); и в-третьих, не желая вести какой-либо содержательный спор, поручик отказывается от участия в последнем, желает пребывать с тем объемом и качеством знания, которое у него сформировалось до разговора с РП. В сущности, поручик настаивает здесь именно на ценности формулы, на ценности “готового” знания и отказывается от какого-либо речепорождения, отказывается от позиции субъекта речи в целом (“а что знаю, то знаю”).

Подобная модальность и стратегия ведения разговора более схожи с теми, что должны реализовываться в рамках не публичной, а частной сферы использования разума. Последнюю Кант понимает как неизбежную уступку Просвещения, которая необходима исключительно для нормального функционирования государственной и социальной систем (например, исполнение солдатами офицерских приказов или исполнение чиновником своих бюрократических обязанностей: как пишет Кант, “здесь [то есть, в рамках частной сферы - прим. СП], конечно, не дозволено рассуждать, здесь следует повиноваться."). ${ }^{34}$ Любопытно, что, пересказывая свои впечатления от беседы с

${ }^{31}$ На “французских” страницах Писем этот локус переместиться в пространство салонов и кофеен: “...после обеда бываю в кофейных домах, где всегда множество людей и где рассказываются вести; где рассуждают о французских делах, о декретах Национального собрания, о Неккере, о графе Мирабо и проч." Карамзин, Письма русского путешественника, 156. (Karamzin, Pis'ma russkogo puteshestvennika, 156). Как пишет Роже Шартье, “общественно-политическая сфера, которая возникла непосредственно из сферы общественно-литературной, опирающейся на салоны, кофейни, газеты, отличается несколькими важными чертами. Во-первых, это пространство, где частные люди публично пользуются своим разумом...” Р. Шартье, “Общественное пространство и общественное мнение,” Культурные истоки французской революции (Москва: Искусство, 2001), 30-48. (R. Chartier, "Obshchestvennoe prostranstvo i obshchestvennoe mnenie," Kul'turnye istoki frantsuzskoi revoliutsii (Moscow: Iskusstvo, 2001), 3о-48). О других локусах публичной сферы, описанных в ПРП, см., например, Rodolphe Baudin, “The Politics of Hot Air Balloons in Karamzin's "Letters of a Russian Traveler'," Вивліоөика: E-Journal of Eighteenth-Century Russian Studies, vol. 7 (2019): 1-20.

32 Кант, “Ответ на вопрос: Что такое Просвещение?,"30-31. (Kant, “Otvet na vopros: Chto takoe Prosveshchenie?," 30-31).

33 Ср. с образцово “просвещенной” речью РП в другом месте Писем: “Победители собрали кости мертвых врагов и положили их близ дороги, где лежат они и поныне [...] Швейцары! Неужели можете вы веселиться таким печальным трофеем? Бургундцы по человечеству были вам братья. Ах! Если бы, омочив слезами сии остатки тридцати тысяч несчастных, вы с благословением предали их земле и на месте победы своей соорудили черный монумент, вырезав на нем сии слова: 'Здесь швейцары сражались за свое отечество, победили, но сожалели о побежденных’ - тогда бы я похвалил вас в сердце своем. Сокройте, сокройте сей памятник варварства! Гордясь именем Швейцара, не забывайте благороднейшего своего имени - имени человека!" Карамзин, Письма русского путешественника, 146-147. (Karamzin, Pis'ma russkogo puteshestvennika, 146-147).

34 Кант, “Ответ на вопрос: Что такое Просвещение?,"29. (Kant, “Otvet na vopros: Chto takoe Prosveshchenie?," 29). 
философом, РП подразумевает совершенно иную модальность ведения разговора. Так, замечание о необходимости “напряжения всех нерв слуха" при разговоре с Кантом может прочитываться здесь не только как метафора необходимости дополнительного интеллектуального усилия, но также и как характеристика обсуждаемого предмета, его дополнительно маркируемая сложность (“Все просто, кроме... его метафизики”), более соответствующая условиям письменного, а не устного обсуждения; ${ }^{35}$ и потому переданная, например, не в форме диалога, как в случае с поручиком, а в форме монолога. ${ }^{36}$ Это, разнородность, необязательность и даже случайность тем и предметов, обсуждаемых Путешественником и философом (“С полчаса говорили мы о разных вещах: о путешествиях, о Китае, об открытии новых земель”) ${ }^{37}$, а также продолжительность их беседы (которая, по утверждению Путешественника, “продолжалась около трех часов,") $3^{8}$ - позволяют говорить о совершенно ином типе ведения разговора, где субъекты не просто ведут познавательный процесс, но и фактически, интенсифицируют сам акт речепроизводства, производят речь ради самого процесса производства речи.

В этом отношении примечательна ремарка Путешественника в седьмом письме о том, что его серебряное перо можно “утомить," что это не просто инструмент письма, а нечто, что вследствие неправильной эксплуатации может износиться, утратить часть своих полезных качеств: описание беседы с поручиком портит перо, неправильно расходует его ограниченный ресурс (“начинает утомлять серебряное перо мое”); в отличие от описания беседы с тем же Кантом, где подобных замечаний не наблюдается. Серебряное перо, будучи орудием фиксации обоих разговоров, позволяет РП маркировать конвенциональность или неконвенциональность поведения его собеседников, эмфатизирует факт использования или неиспользования ими Приемов Просвещения. Поручик, находясь в рамках публичной сферы, отказывается от разговора, не воспринимает просвещенческое побуждение к речи, и это неконвенциональный поведенческий паттерн; Кант же, находясь в почти что тех же самых условиях, активно и свободно говорит, активно и свободно участвует в дискуссии, и это конвенциональный поведенческий паттерн. В указанной перспективе дом философа может быть также определен как локус публичной сферы в силу того, что РП попадает в него, не будучи лично знакомым с Кантом (“Я не имел к нему [Канту —

\footnotetext{
35 В этой перспективе важно, что Кант настаивает, прежде всего, на пользе письменного, а не устного дебата, на силе письменного, а не устного слова. Шартье полагает, что этот медиальный аспект принципиально важен для Канта и его понимания публичной сферы, технологии последней: «Единство этого общества граждан мира обеспечивается хождением письменного слова, ибо оно делает возможным обмен мыслями и идеями. Это очень важно для Канта, и “публичное использование разума' неизменно ассоциируется у него с созданием или чтением письменного слова.” Шартье, “Общественное пространство и общественное мнение," 37. (Chartier, “Obshchestvennoe prostranstvo i obshchestvennoe mnenie," 37).

${ }^{36}$ Как отмечает Герда Панофски, “Отражение европейской эстетики XVIII века в "Письмах русского путешественника,” в Карамзин-писатель: коллективная монография, ред. Н. Д. Кочетковой, А. Ю. Веселовой и Р. Бодэна (Санкт-Петебург: Пушкинский Дом, 2018), 27-45, здесь 43-44 (Gerda Panofski, “Otrazhenie evropeiskoi estetiki XVIII veka v 'Pis'makh russkogo puteshestvennika', Karamzin-pisatel': kollektivnaia monografiia. Pod. red. N. D. Kochetkovoi, A.I u. Veselovoi, R. Bodena (St. Petersburg: Pushkinskii Dom, 2018), 27-45, here 43-44) - разговоры РП с другими немецкими интеллектуалами (например, с Виландом) и остальными персонажами Писем были описаны в диалоговой форме, тогда как в монологической - только беседа с Кантом. Это, в свою очередь, не просто выделяет речь Канта как исключительно важную, но и проблематизирует сам способ ее описания в ПРП.

37 Карамзин, Письма русского путешественника, 2о. (Karamzin, Pis'ma russkogo puteshestvennika, 20).

$3^{8}$ Карамзин, Письма русского путешественника, 21. (Karamzin, Pis'ma russkogo puteshestvennika, 21).
} 
прим. CП] писем; но смелость города берет (sic!) - и мне отворились двери в кабинет его”): ${ }^{39}$ философ видит в своем доме не столько интимное пространство, сколько место для проведения встреч, локус публичной сферы. Или, если словами из знаменитой работы 1784-го года, он предстает в нем “как ученый перед всей читающей публикой”; $4^{\circ}$ (публикой, читающей в том числе - и ПРП).

Более того, ремарка об “утомляемости” пера - при более проспективном чтении, то есть в перспективе ее восприятия актуальным читателем произведения - позволяет выдвинуть еще одну интерпретацию: перо как технологический дар просвещенного общества требует не только “правильных" условий эксплуатации (то есть, конвенциональности им записываемого), но и “правильного” же владельца (то есть, так же использующего Приемы Просвещения, просвещенного субъекта); в то время как непросвещенному субъекту, следовательно, в праве пользоваться последними европейскими технологическими новинками должно быть отказано. Метонимически рифмуя технологическую новизну серебряного пера и свою интерпретацию последних европейских интеллектуальных мод, ассоциативно замещая возможность нормативной оценки различных поведенческих моделей и речевых практик субъектов бытовыми аспектами используемых ими повседневных аксессуаров (и тем, какой стиль жизни они формируют), - Карамзин производит в данном случае некое новое знание, уникальную культурную практику; фактически, имплицитную политическую манифестацию.

Вновь апроприируя и остраняя “чужое” знание, Карамзин задает последнему иной способ интерпретации, иную модель прочтения. Пользоваться серебряным пером - не значит, определять себя как “высокого” автора или написанный им текст как “высокий,” особенно ценный (для автора-сентименталиста подобные номинации, в целом, являются неприемлемыми). Пользоваться серебряным пером, европейской вещью значит, подчиняться тем идеологическим декларациям, что господствуют на данный момент в европейской цивилизации. Серебряные перья, только что появившиеся в широкой продаже (а значит, и изготовляемые стандартизированным, промышленным способом) и дающие своему пользователю больший уровень повседневного комфорта, оказываются в данном случае наиболее удобным поводом для формулирования и артикуляции столь важных для Карамзина идей и наблюдений о принципах устройства модерного общества. ${ }^{41}$ Находясь в Британии, Путешественник запишет:

Я всегда думал, что дальнейшие успехи просвещения должны более привязать людей к домашней жизни... Первое дело истинной философии есть обратить человека к неизменным удовольствиям натуры. Когда голова и сердце заняты дома приятным образом; когда в руке книга, подле

\footnotetext{
39 Карамзин, Письма русского путешественника, 2о. (Karamzin, Pis'ma russkogo puteshestvennika, 20).

${ }^{40}$ Кант, “Ответ на вопрос: Что такое Просвещение?,"29. (Kant, “Otvet na vopros: Chto takoe Prosveshchenie?," 29).

${ }^{41}$ Стоит, впрочем, напомнить, что серебряное перо предоставляет не только определенный уровень комфорта, но и также - является предметом роскоши, предметом элитарного потребления. О Карамзине и роскоши см., например, Elena Korchmina, Andrei Zorin, "Karamzin and Money," Cahiers du monde russe, 59:1 (2018): 117-140. О потреблении и его связи с дискурсом модернизации и вестернизации в ПРП см. также: Rodolphe Baudin, "Shaping National Identities and Politics: French and British Foodways in Karamzin's Letters of a Russian Traveler," A Century Mad and Wise, Russia in the Age of the Enlightenment, eds. E. Waegemans, H. van Koningsbrugge, M. Levitt and M. Ljustrov (Groningen: Netherlands Russia Center, 2015), 7991.
} 
милая жена, вокруг прекрасныя дети, захочется ли ехать на бал, или на большой ужин $?^{42}$

Просвещенное, модерное общество для Карамзина - это так же, как и для британцев, в том числе и общество с наибольшими потребительскими возможностями, технологически развитое общество. ${ }^{43}$ Импортируя в Россию, для русского читателя серебряные перья, ${ }^{4}$ связанные с ними культурные и повседневные практики, Карамзин, соответственно, импортирует и модерный мир, служит своего рода культуртрегером, агентом модернизации русского общества.

\section{Литературное письмо как игра, или к определению функциональных признаков текста Писем}

Тем не менее, высокая суггестивность значения серебряного пера, а также то, насколько сложным оказался процесс его обнаружения и идентификации в тексте Писем, ставит новые исследовательские вопросы.

Роман Якобсон считал, что установка на производство метонимически устроенных, чрезвычайно трудных для понимания высказываний есть следствие дефекта селекции, то есть афатического нарушения речи, ${ }^{45}$ каковой в случае Карамзина мог быть спровоцирован - разнообразными цензурными ограничениями и авторитарным характером российского государства в целом ${ }^{46}$ (в частности, в момент написания ПРП Карамзину еще были памятны дела Радищева и его друга Новикова). Травматичность биографического и социального опыта, страх политического преследования, таким образом, лишают автора возможности создавать осмысленные сообщения и, следовательно, заставляют его скрывать, шифровать истинный смысл своего текста. Подобная интерпретация, однако, в очередной раз объективирует Карамзина, объясняет сложность его произведения в излишне простых категориях. Справедливее и логичнее предположить, что выявленная тенденция ПРП это результат восприятия (или точнее - конструирования) Карамзиным особого стиля литературного письма.

\footnotetext{
42 Карамзин, Письма русского путешественника, 366-367. (Karamzin, Pis'ma russkogo puteshestvennika, 366-367).

${ }^{43}$ Chris Evans and Alun Witney, "An Enlightenment in Steel? Innovation in the Steel Trades of EighteenthCentury Britain," Technology and Culture, vol. 53 (2012): 533-560.

${ }^{44}$ На то, что металлическое перо может быть символом модернизации и модерности, указывает, в частности, исследователь Сеймур Ховард, когда пишет: "it seems singularly appropriate that one of the first and most refined products of modern steel manufacture was the indefatigable pen, which everyday recorded the images, means, and ideals of the new era." Seymour Howard, The Steel Pen and the Modern Line of Beauty," Technology and Culture, 26 (1985): 785-798, здесь, 791. Основываясь на материале европейской культуры конца XVIII-начала XIX века, Ховард прочитывает в откликах на наступление новой технологической эпохи - мотивы именно модерного характера (что косвенно - объясняет и карамзинские интенции).

45 Роман Осипович Якобсон, “Два аспекта языка и два типа афатических нарушений,” в Формальный метод. Антология русского модернизма, т. 3 (Екатеринбург: Кабинетный ученый, 2016), 428-454, здесь, 434-442. (Roman Osipovich Jakobson, "Dva aspekta iazyka i dva tipa afaticheskikh narushenii," v Formal'nyi metod. Antologiia russkogo modernizma, t. 3 (Ekaterinburg: Kabinetnyi uchenyi, 2016), 428-454, zdes' 434-442). ${ }^{46} \mathrm{O}$ том, как политические процессы влияют и трансформируют средства репрезентации отдельных частных акторов, см. Сергей А. Ушакин, “Бывшее в употреблении: Постсоветское состояние как форма афазии," Новое литературное обозрение, № 100(2009): 760-792. (Sergei A. Ushakin, "Byvshee v upotreblenii: Postsovetskoe sostoianie kak forma afazii," Novoe literaturnoe obozrenie, no. 100 (2009): 760-792).
} 
И тогда то, что анализировалось через якобсоновскую категорию афазии, в действительности, следует интерпретировать, к примеру, через концепт языковой игры Людвига Витгенштейна. Смена аналитической оптики в данном случае - не выбор вкуса или предрасположенности к той или иной аналитической традиции, а выбор наименее очевидного и конвенционального (“профессионального”) способа прочтения. Теоретическая установка Витгенштейна на толкование любого речевого явления как “компонента некоторой деятельности, некоторой формы жизни” 47 позволяет не только оценить сложность Писем для чтения как акт свободного решения их автора; но и дает возможность описать ряд функциональных, прагматических признаков последних. Так, например, имплицитный призыв к интеракции с текстом, реализованный Путешественником в модели сокрытия значения пера (и которое читателю, соответственно, необходимо найти), - оказывается функциональном признаком удовольствия Писем, важной составляющей игрового процесса как такового; ${ }^{8}$ а сравнительно небольшой объем текстового пространства, в рамках которого происходит этот поиск, работает как функциональный признак интенсификации читательского внимания к общей конструкции текста.

Более того, не травма и не желание произвести дидактический образ для читателя (или для самого себя), а именно игра, понимание литературного письма как преимущественно игрового по своему характеру - и мотивировали Карамзина не самому отправиться в Европу и описать ее в Письмах, а перепоручить это дело Путешественнику. Дополнительная противоречивость, конфликтность, внесенная в ПРП с появлением такого посредника, лишь увеличивает общий “игровой” потенциал произведения. ${ }^{49}$ И список этих признаков - может лишь пополняться.

Самое любопытное же то, что подобный тип литературного письма в конечном итоге стал для Карамзина также и способом производства политических деклараций $5^{\circ}$ и к тому же, весьма успешно усвоенных русским обществом и во многом ставших основой для русского общественно-политического дискурса. ${ }^{51}$

\footnotetext{
47 Л. Витгенштейн, “Философские исследования,” в Новое в зарубежной лингвистике, вып. 16 (Москва: Прогресс, 1985), 79-129, здесь 88. (L. Wittgenstein, "Filosofskie issledovaniia," Novoe v zarubezhnoi lingvistike. vyp. 16 (Moscow: Progress, 1985), 79-129, zdes' 88).

$4^{8}$ Р. Барт, “Удовольствие от текста," в Избранные работы: Семиотика, поэтика, пер. и ред. Г. К. Косикова (Москва: Прогресс, 1989), 462-519. (Roland Barthes, "Udovol'atvie ot teksta," Izbrannye raboty: Semiotica, poetika, per. i red. G. K. Kosikova (Moscow: Progress, 1989), 462-519).

49 Для проверки этого предположения было бы любопытно также обратиться к более широкому контексту актуальной для Карамзина европейской литературы: к примеру, к Стерну, чей Йорик - по многим признакам, в первую очередь, функциональным - напоминает то, как устроен РП.

${ }^{50}$ О характере политического влияния Писем см. подробнее, например, J. L. Black, Nicholas Karamzin and Russian Society in the Nineteenth Century: A Study in Russian Political and Historical Thought (Toronto: The University of Toronto Press, 1975), 3-34.

${ }^{51}$ С блестящим анализом влияния Карамзина - и преимущественно на материале Писем - на язык русской общественной дискуссии можно ознакомиться в книге Кирилла Кобрина, Разговор в комнатах. Карамзин, Чаадаев, Герцен и начало современной России (Москва: Новое литературное обозрение, 2018). (Kirill Rafailovich Kobrin, Razgovor v komnatakh, Karamzin, Chaadaev, Gertsen i nachalo sovremennoi Rossii (Moscow: Novoe literaturnoe obozrenie, 2018).
} 
Старообрядцы, школьные учителя - идейные последователи критиков Карамзина - не пользовались и отказывали другим в праве пользоваться металлическими перьями до конца XIX века, видя в этом угрозу границам своей культурной идентичности (по словам Черепнина, “такими мерами достигалась консервация старинных типов письменности.") $5^{2}$ В годы советской культурной революции вопрос о вещах и тех перформативных изменениях, что они производят, хотя содержательно и значительно трансформировался (чего не скажешь о механике просвещенческого принуждения к речи), но по-прежнему был таким же значительным, ${ }^{53}$ что и в конце XVIII века. Лишь в пост-советской России проблема соотношения вещей, их культурного происхождения и политических симпатий их владельцев обрела тот же вид, в каком была сформулирована Карамзиным - метафорически определив язык “вестернизованной” части страны как “язык айфона,” а язык противников последней как “язык шансона." 54

Однако то, по каким причинам в России начала XXI века вновь актуализируется дискурс модернизации конца XVIII столетия и эксплуатируемые им риторические модели (обретающие, в свою очередь, черты образцового социального и культурного расизма); 55 и почему вообще подобные архаизмы, словно следуя в данном случае беньяминовскому подходу к истории и историческому знанию, оказываются частью современного русского политического языка - уже дело отдельных, куда более сложных разысканий.

\footnotetext{
52 Черепнин, Русская палеография, 542. (Cherepnin, Russkaia paleografiia, 542).

53 О. М. Брик, “Ближе к факту,” Литература факта: Первый сборник материалов работников ЛЕФа (Москва: Захаров, 2000), 80-86. (О. M. Brik, "Blizhe k faktu," Literatura fakta: Pervyi sbornik materialov rabotnikov LEFa (Moscow: Zakharov, 2000), 80-86).

54 Юий Геннадьевич Сапрыкин, La Prude, Бликующая гопота. Как жить с таким народом," Aфиша Daily (30.8.2010). (Iurii Gennad'evich Saprykin, "La Prude. Blikuiushchaia gopota. Kak zhit's takim narodom," Afisha Daily [30.8.2010]). URL: https://daily.afisha.ru/archive/gorod/archive/sapr gopota/.

${ }^{55}$ См. также: “Я и народ - мы по-разному едим, по-разному одеваемся, по-разному развлекаемся, поразному работаем. Любим разное [...] Я, например, пью вино, а народ пьет водку (и неизвестно, кстати, что честнее). Я считаю лакомством устрицы и трюфели (и неизвестно, снобизм ли это мой или развитый вкус). А народ считает лакомством пельмени. Из музыки я слушаю Хейфеца или Гульда, а народ слушает Стаса Михайлова или Ёлку. Когда в музыкальных вкусах я хочу быть ближе к народу, то слушаю Тома Уэйтса - ближе не могу [...] На первый взгляд, единственная общая для нас вещь - это презрение друг к другу. Всех этих людей, таких разных, я легко описываю словом “народ,” которое в моих устах звучит в лучшем случае снисходительно [...] Объединяющее нас презрение - это негативное чувство, не способное никого объединить." В. Панюшкин, “Что общего у меня с народом,” Сно6 (3.4.2012). (Valerii Valer'evich Paniushkin, "Chto obshchego u menia s narodom," Snob [03.04.2020]), URL: https://snob.ru/selected/entry/47631/ Метафорический перенос актов престижного потребления на политическую и идеологическую проблематику - в данном случае еще более характерный, чем в указанном выше тексте Юрия Сапрыкина.
} 